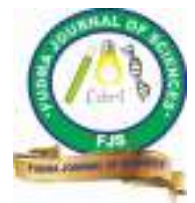

\title{
PROFITABILITY ANALYSIS OF MARKETING OF FROZEN FISH IN KADUNA METROPOLIS, KADUNA STATE, NIGERIA
}

\author{
Usman, M. B., Aaasa, O. S., *Balogun, O. S. and Yahaya, U. F. \\ Federal college of Forestry Mechanization Afaka, Kaduna. Kaduna state, Nigeria \\ s \\ *Corresponding Author's Email: baaseg2006@yahoo.com
}

\begin{abstract}
This study investigated the marketing of frozen fish in Kaduna metropolis, Kaduna state. Ten (10) markets were purposively selected due to high concentration of frozen fish marketers and the volume of trading activities; Primary data were generated through the use of structured questionnaire administered to hundred (100) randomly selected retailers and fifteen (15) purposively selected wholesalers. The data were analyzed using descriptive statistic, budgeting technique, net marketing and rate of return on capital invested. The result show that majority 80 percent and 53 of the retailers and wholesalers were female, Majority (70prcent) of the retailers had primary education but most of the wholesaler's attained tertiary education. The frozen fish marketing channels identified in the area are made up of zero and multi stage channels. Furthermore, the cost and return analysis revealed that the wholesalers realized about N121, 000.00 naira while the retailers got N56, 000.00 naira per month while return to per capital invested (RPCI) was 11 kobo and 22 kobo per Naira invested for the wholesalers and the retailers respectively. This implies that the enterprise is profitable. Transportation difficulties and marketing charges ranked were major constraints confronting frozen fish marketers. It is recommended that provision of good roads network and formidable integrated marketing system will further improve the profitability of the enterprise in the study area.
\end{abstract}

Keywords: Profitability, Retailers, Wholesalers and Frozen Fish

\section{INTRODUCTION}

Fish plays a vital role in feeding the world's population and contribute significantly to the dietary protein intake of billions of the populace. On the global scale, almost $20 \%$ of total average intake of animal protein was attributable to fish in 2012 (FAO, 2014). Fish is also a good source of sulphur and essential amino acids such as lysine, leucine, valine and arginine and it is therefore suitable for supplementing diets of high carbohydrates contents. It has high content of polyunsaturated (Omega III) fatty acids, which are important in lowering blood cholesterol level and high blood pressure. It has also been affirmed to have decreased the risk of bowel cancer and reduces insulin resistance in skeletal muscles (Coaster and Otufale, 2010).

The fish industry remains the most virgin investment in Nigeria, Similarly the demand for fish in the country has been on the rise with demand far exceeding supply. Although the country imports a lot of frozen fish; there exist a demand-supply gap put at 2.7 million metric tonnes, thus the country is faced with a deficiency of about 1.9 million metric tonnes (Ndu, 2006). Processing and marketing of agricultural products like frozen fish is becoming a problem in Nigeria. This is not necessarily because supply is in excess of demand but because of uncoordinated marketing programmes. Frozen fish marketing provide employment to large population of stakeholders among which includes processors, traders (wholesalers and retailers). Effective processing and marketing of frozen fish could bring about increased consumption rate which in turn will increase the demand for the product. Also, increase demand of frozen fish could lead to increase in price which would bring more money in terms of profit margin to frozen fish marketers and processors but there exists a lacuna in information on the enterprise marketing potentials in the study area that can serve as a guide to stake holders (fish marketers, farmers, government and nongovernmental agencies) in understanding the prevailing marketing opportunities of frozen fish within and outside the study area. Hence, this study provided answers to the following research questions. What are the socio-economic characteristics of the fish sellers? What is the marketing channel? What are the differences in the cost and returns of the wholesalers and retailers? What are the major constraints affecting the marketing of frozen fish in the study area? The general objective of the study was to examine the marketing of frozen fish in the study area while specifically it describes the socio-economic characteristics of the fish marketers, describe the marketing channel of frozen fish in the study area, estimate the costs and returns of the fish marketers and identify the major constraints of frozen fish marketing in the study area.

\section{CONCEPTUAL FRAMEWORK AND LITERATURE REVIEW}

Market researchers such as (Aasa 2006), asserted that marketing is an exchange of goods between buyers and sellers who are attempting to maximize profit or subjective utility. And it may also be looked at as the process of making goods available for consumption. The primary role of an integrated marketing system is to add form, place, time and possession utility so that the subjective satisfaction of consumers is maximized. Hence, 
marketing of fish involves the movement of fish in its form from one hand to another or from one location to another until it reaches the consumer. Fish marketing describes the various activities from the point of catching/harvesting of fish, to processing and ultimately to the point of final consumption. Also despite the nutritional and commercial values of fish and fish products, its production and marketing remains low in Nigeria when compared to other nations of the world (FAO, 2012).

Processing and marketing of agricultural products like frozen fish is becoming a problem in Nigeria. This is not because supply is in excess of demand but because of uncoordinated marketing programme. when one studies the marketing on this basis of commodity approach, one must begin to study and analyse the problems relating to a commodity in term of sources and conditions of supply, nature and extent of demand, mode of transporting, storage ,standardization, packaging etc. We get a full picture of the facilitating services for marketing channels such as the provision of infrastructure, market information and documentation support. In the institutional approach, the focus is on the study of institution-middlemen, i.e wholesalers, retailers, importers, agencies, warehousing etc that are engaged in the marketing during the movement of goods. The approach is also known as middlemen approach Hence, emphasis is given to understanding and analysing the functions of institutions discharging their marketing functions. The activities of each institution form a part of marketing and collectively complete marketing functions (Olukosi and Isitor, 1990).

Marketing Efficiency (M E) can be defined as the movement of crops and livestock from the marketers to consumers at the lowest cost consistent with the provision of the services consumers' desire. To the farmer, M E means selling his produce at the highest price, on the other hand, to the consumer it may mean getting the commodities at the lowest price. The aim of overall $\mathrm{M} \mathrm{E}$ is to provide goods to consumers in the required form, at the required time and place with the lowest possible marketing costs consistent with the interest of the marketers (Adegeye and Dittoh, 1985). Indicators usually identified with M E are marketing margin, consumers' price, availability of marketing physical facilities and market competition. The success of the efficiency of a marketing system is consumers' satisfaction with goods and services. Efficient marketing can be seen as maximization of input-output ratio. This implies that an efficient agricultural marketing system involved the movement of crops and livestock from the marketers to consumers at the lowest cost consistent with the provision of the services consumers' desire. To the farmer, M E means selling his produce at the highest price, on the other hand, to the consumer it may mean getting the commodities at the lowest price. The aim of overall M E is to provide goods to consumers in the required form, at the required time and place with the lowest possible marketing costs consistent with the interest of the marketers (Adegeye and Dittoh, 1985).

Marketing Margin (MM), according to Olukosi and Isitor (1990) refers to the difference in price paid for a commodity at different stages of the marketing system. That is, it is the difference between average price paid by the consumer and the payment the farmer receive. It reflects difference in price of the commodity at different stage of time, place, form and possession and differs from product to product. Among the factors known to affect marketing margin are; bulkiness, processing, perishability, seasonality, institutional factors such as vertical integration, and so on.

\section{MATERIALS AND METHODS}

Study Area: Kaduna metropolis is made up of four Local Government Areas, namely; Kaduna North, Kaduna South, Igabi and Chikun Local Government Areas. Kaduna state lies between latitude $10^{0} 37^{1} \mathrm{~N}$ and longitude $7^{0} 17$, E and its coordinates is $10^{\circ} 20^{\circ} \mathrm{N}$ and $70^{\circ} 45^{\mathrm{E}} \mathrm{E}$ (Wikipedia). It has a projected population of about $8,252,366$ people according to the National Bureau of Statistics NBS (2018). According to Wikipedia, Kaduna state has a total land area of about 46,053 square kilometer and the density is about 131.7 square Kilometers (341.2 square metre). The metropolis is a commercial and industrial centre in Nigeria, the city has many factories such as textile, beverages, furniture, etc. It is a rail and road junction, thus, a trade centre for the surrounding agricultural areas. The city was founded by the British in 1913 and became the capital on $25^{\text {th }}$ May, 1967 of Nigeria former Northern region. It got her name after the Kaduna river which flows through the centre of the state and on which the city lies (Wikipedia). The area is marked with two distinct seasons of wet and dry. The major ethnic groups in the city are the Hausas, Gwaris, Katafs, Gbagijs and Jaba form the majority of the inhabitants of the area. Others include the Fulanis, Tiv, Idoma, Yoruba and Ibos. It has a mean annual rainfall which varies from 1152-635mm.

Sampling Techniques and Data Collection;

A multistage sampling technique was employed for the sampling. First, a purposive sampling of four(4) L.G.As ( Kaduna North, Kaduna South, Chikun, and Igabi) in Kaduna metropolis were selected because of their high population of frozen fish marketers, Furthermore, some markets were selected based on the volume of trade activities. Finally, one hundred and fifteen (115) marketers made up of one hundred retailers and fifteen wholesalers were sampled for the study as presented in table 1. Personal observation and interview schedule, weighing and observation methods were also employed to complement data gathered through the questionnaires. 
Table 1. Description of Sampled Marketers

\begin{tabular}{|c|c|c|}
\hline Market & Wholesalers & Retailers \\
\hline $\begin{array}{l}\text { Central market/Barkin-Dogo, AngwaRimi and Kawo } \\
\text { markets (Kaduna North) }\end{array}$ & 5 & 35 \\
\hline KasuaBechi, Barnawa and Kakurimarkets (kaduna South) & 5 & 30 \\
\hline Gonigora and Sabo markets (Chikun) & 3 & 15 \\
\hline Rigasa and Mando markets (Igabi) & 2 & 15 \\
\hline Total & 15 & 100 \\
\hline
\end{tabular}

Source: Field Survey 2018.

Analytical Technique. Data were analyzed using measures of central tendency such as percentages, frequency distribution, arithmetic mean, standard deviation; ranking to achieve the objectives of the study.

\section{Specifications}

Marketing Margin (MM) and Marketing Efficiency (ME): Tomek and Robinson, (1981) defined marketing margin as the price of a collection of marketing services. Hence, marketing margin can be calculated by subtracting supply price from urban selling price.

Therefore, $M M=U S P-S P$

Where

$M M=$ Marketing margin

$U S P=$ Urban selling price

$S P=$ Supply price

However, when expressed as percentage;

$$
. M M=\quad \frac{\text { Urban Selling Price-Supply Price } X 100}{\text { Urban selling price }}
$$

The underlying assumption was that the retailers buy directly from their suppliers wholesalers (within the metropolis), this means that the marketers' margin equals to urban selling price (the amount consumers paid) minus supply price (initial purchasing price), and a wide variation in this is an indication that the market is not operationally efficient. According to Olukosi and lsitor, (2008), M E is expressed as:

$. M E=\frac{\text { Value added by Marketing } \times 100}{\text { Cost of Marketing }}$

(2)

where; Value Added by Marketing means those activities performed by the marketers to make the commodity attractive to the consumers. Cost of Marketing Services refers to transportation and storage costs, charges by government and $\mathrm{RPCI}=\frac{N I}{T R}$

\section{RESULT AND DISCUSSION}

Socio-Economic Characteristics of Major Frozen Fish Marketer in the Study Area.

The socio economic characteristics examined were Gender, Age, Marital status, education background, marketing experience, etc. Table 2 show that 46.67 percent of frozen fish wholesalers were males while 53.3 percent were female. On the other hand 20 percent of frozen fish retailers were male while 80 percent were female. These shows that female constitute the other expenses. Thus, total marketing cost indicate the amount of money incurred by the marketers at the expense of suppliers and the final consumer However, in this study M.E. was obtained using net marketing margin as a percentage of the cost of marketing (Tomek and Robinson, 1981, Ben Ahmed and Omolehin, 1999). That is,

$$
M E=\frac{\text { Net Marketing Margin } X 100}{\text { Marketing Cost }}
$$

These models were used to calculate both the marketing margin (MM) and marketing efficiency (ME).

Net income, is the total monetary returns to the enterprise, it is expressed as

$N I=T R-(T V C+T F C)(4)$

$N I=T R-T C$

where,

$(T V C+T F C)=T C, N I=$ Net income $(\$), T F C=$ total fixed cost $(\#), T V C=$ total variable cost $(\#), \quad T C=$ total cost $(\#)$, $\mathrm{TR}=$ total revenue $(\AA)$

\section{Measure of profitability ratio}

The measures of profitability that were used to determine the level of profit for both the retailers and wholesalers includes; Return per capital invested (RPCI) which indicates the amount of money return to the investors on every naira invested. This was expressed as

majority of frozen fish marketers in the study area. The table further revealed that 40 percent and 46.15 percent of the retailers and wholesalers are aged between $31-40$ year. The results also shows that about 31 percent had no formal education among the retailers but all the wholesalers had one form of formal education or the other however, only 3 percent of the retailers had primary education while about 40 percent of the wholesalers had tertiary education showing that retailers level of education was lower than those of the wholesalers. The volume of the 
wholesale enterprise requires high literacy to cope with wholesaling activities, this might be responsible for the relatively high educated individuals involved in the wholesale, this was similar to the findings of Aasa, Ariyo, Olagunju and Olafemi (2011) in their study on the marketing of irish potato in Kaduna metropolis. Although good education will help boast and promote business management, the low level of education of the respondents (retailers) may not necessarily deprive them from business although there were reports of problems in keeping accurate records of their business.

Furthermore, on the basis of sources of finance, personal savings constituted about 32 percent and 20 percent of the source of finance for the retailers and Wholesalers respectively.
Forty percent (40 percent) of retailers finances were sourced from Cooperative societies while (46.67 percent) of the wholesalers source from commercial banks these however does not come with surprise since the volume of monies required by the wholesalers are relatively large compared to the retailers. This agreed with the result of Aasa, Alabi, Ariyo, Awotide and Adetunji (2015). Moreover, the wholesalers had a mean marketing experience of 19 years compared to 16.8 years for the retailers. About 46.67 percent of the wholesalers had marketing experience of between 21-30 years compared to about 38 percent of the retailers with same years of experience, from these findings; it seems the wholesalers are more experienced compared with their retailer counterparts.

Table 2. Socio-economic Characteristics of Frozen Fish Marketers.

\begin{tabular}{|c|c|c|c|c|}
\hline \multirow[t]{2}{*}{ Characteristics } & \multicolumn{2}{|l|}{ Retailers } & \multicolumn{2}{|l|}{ WholeSalers } \\
\hline & Frequency & Percentage & Frequency & Percentage \\
\hline \multicolumn{5}{|l|}{ SEX } \\
\hline Male & 20 & 20.00 & 7 & 46.67 \\
\hline Female & 80 & 80.00 & 8 & 53.32 \\
\hline \multicolumn{5}{|l|}{ Age } \\
\hline $21-30$ & 24 & 24.00 & 4 & 26.67 \\
\hline $31-40$ & 25 & 25.00 & - & - \\
\hline $41-50$ & 21 & 21.00 & 5 & 33.33 \\
\hline $61-60$ & 30 & 30.00 & 6 & 40.00 \\
\hline Mean 41 & & & 43 & \\
\hline \multicolumn{5}{|l|}{ Household size } \\
\hline $1-5$ & 35 & 35.00 & 8 & 53.33 \\
\hline 6-10 & 50 & 50.00 & 4 & 26.67 \\
\hline $11-15$ & 15 & 15.00 & 3 & 20.00 \\
\hline Mean 6.5 & & & 10 & \\
\hline \multicolumn{5}{|l|}{ Level of education } \\
\hline No formal & 30 & 30.76 & - & \\
\hline Primary & 27 & 27.00 & 2 & 13.33 \\
\hline Junior Secondary & 25 & 25.00 & 3 & 20.00 \\
\hline Senior Secondary & 15 & 15.00 & 4 & 26.61 \\
\hline Tertiary & 3 & 3.00 & 6 & 40.00 \\
\hline \multicolumn{5}{|l|}{ Source of Finance } \\
\hline Personal Savings & 32 & 32.00 & 3 & 20.00 \\
\hline Commercial Banks & 15 & 15.00 & 7 & 46.67 \\
\hline Cooperative & 40 & 40.00 & 5 & 33.33 \\
\hline Micr-Finance & 13 & 13.00 & - & - \\
\hline \multicolumn{5}{|c|}{ Marketing Experience } \\
\hline $5-10$ & 18 & 18.00 & 1 & 6.67 \\
\hline $11-15$ & 24 & 24.00 & 2 & 13.33 \\
\hline $16-20$ & 20 & 20.00 & 5 & 33.33 \\
\hline $21-25$ & 30 & 30.00 & 4 & 26.67 \\
\hline $26-30$ & 8 & 8 & 3 & 20.00 \\
\hline Mean & & & 19 & \\
\hline
\end{tabular}

Source: Field survey 2018

The Marketing Channels.

Marketing channel can be defined as the path of commodity from its raw to its finished form. It's also the path of the product as it moves from the producer to the final consumer. From the study the path that frozen fish passes from the producer to the consumer is shown in figure I

Two channels identified in the study include, major and minor channels. The major channel involves the movement from wholesalers to the retailers and flows from the retailers to the final consumer which follows the proper and normal flow channel of the frozen fish; this was indicated in the channel by tick arrow while the less important (minor) channel is represented by the arc arrow line. 

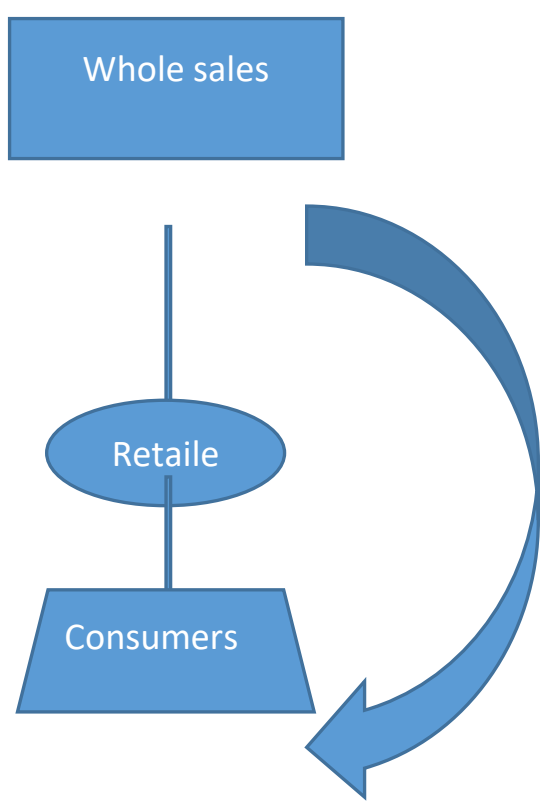

Figure 1 The Marketing Channel of frozen fish marketing in Kaduna Metropolis.

Cost and Return Analysis for Frozen Fish in the Study Area
In this study, it was observed that Shawa was the most commonly sold species in all the selected markets in term of quantities sold by both the wholesalers and retailers, since it is the most consumed of all the species of frozen fish in Kaduna metropolis. As reported by the marketers, Shawa is said to be the most readily available and the price is relatively affordable to both the retailers, the low and medium income consumers hence, Shawa was used for this analysis. Table 3 shows the prices of all common species of frozen fish in the selected markets in Kaduna metropolis.

The total fixed cost for the retailers was $\$ 96,560.00$ constituting about 48.87 percent of the total cost while the total fixed cost for the wholesalers was estimated at $\$ 664,940.00$ naira constituting 70.76 percent of the total cost. The huge outlay on fixed assets and electricity were largely responsible for the high proportion of the fixed cost incurred by the wholesalers compared to the retailers. Furthermore, a variable cost of $\$ 101,560.00$ constituting $(51.12 \%)$ and $\$ 274,800.00$ constituting about 48.88 percent of the total costs for the retailer and the wholesalers respectively were obtained. Also, about 41.41 percent of the variable cost was expended on acquisition cost, this finding was in agreement with that of Esiobu and Onubuogu, (2014) who reported acquisition cost of about 59.86 percent. The retailer made a profit of $\$ 56,000.00$ naira while the wholesalers realised a profit of about $\$ 121,000.00$ naira. An estimated Return per capital invested (RPCI) 0.11 and 0.22 for the wholesalers and retailers respectively were recorded. This means that for every Naira invested by the wholesalers, 11 kobo gain was realized while the retailers got 22 kobo implying also that the enterprise is profitable.

Table 3. Cost and Returns Analysis of the Retailers and Wholesalers

\begin{tabular}{|c|c|c|c|c|}
\hline Items & $\begin{array}{c}\text { Whole Salers } \\
(\mathrm{N})\end{array}$ & $\begin{array}{l}\text { Percentage of TC } \\
\text { cost }\end{array}$ & $\begin{array}{l}\text { Retailers } \\
(\mathbb{A})\end{array}$ & $\begin{array}{l}\text { Percentage of } \\
\text { TC cost }\end{array}$ \\
\hline Total Revenue & 1726140 & & 348990 & \\
\hline Transportation & 105000.00 & & 7560.00 & \\
\hline Wages & $35,800.00$ & & 8500.00 & \\
\hline Carriages & 9000.00 & & 26000.00 & \\
\hline Packages & 5000.00 & & $35,000.00$ & \\
\hline General expenses & $120,000.00$ & & $20,000.00$ & \\
\hline Total variable cost & $274,800.0029$ & 24 & $101,560.0051$. & 12 \\
\hline Gross Margin & $786,400.00$ & & $151,430.00$ & \\
\hline Fixed Cost & & & & \\
\hline Fixed asset (Cooling & $350,000.00$ & & 51.400 .00 & \\
\hline Repairs & 43000.00 & & $2,500.00$ & \\
\hline Interest & $76,300.00$ & & $20,200.00$ & \\
\hline Electricity & $98,640.00$ & & $23,400.00$ & \\
\hline Salary & $87,900.00$ & & - & \\
\hline TFC & $664,940.0070$ & 76 & $96,560.0048$ & 88 \\
\hline Total Cost (TC) & $939,740.00$ & & $197,560.00$ & \\
\hline Net Income & $121,460.00$ & & $56,340.00$ & \\
\hline Rate of Return & 0.11 & & 0.22 & \\
\hline
\end{tabular}

Source: Field survey 2018

\section{Marketing Cost and Price Differential of Frozen Fish in the Selected Markets}

Table 4 shows that there are variations in the average prices of the different frozen fish sold within the city from one market to the other. The standard deviation (SD) associated with the different species shows that Sadine has the highest price differential with a standard deviation of 153.11 and a price range of $\$ 500$ between Kakuri, Kasuan-bachimarket and Barnawa 
PROFITABILITY ANALYSIS OF MARKETING ...

markets. Makre and Argentine also exhibited a relatively high compared to Coaker with SD of 66.87 and Shawa with a SD of variation with an SD of about 102.74 and price range of $\$ 300 \quad 62.40$ and Price range of $\$ 200$ and $\$ 150$ respectively.

Table 4. Marketing Cost and Price Differential of Frozen Fish in the Selected Markets

\begin{tabular}{|c|c|c|c|c|c|}
\hline \multirow[b]{2}{*}{ Market } & \multicolumn{4}{|c|}{ Fish Species and Prices } & \multirow[b]{2}{*}{$\begin{array}{l}\text { Argentine } \\
\text { (Price N) }\end{array}$} \\
\hline & $\begin{array}{l}\text { Shawa (Price } \\
\text { N) }\end{array}$ & $\begin{array}{l}\text { Sadine (Price } \\
\text { N) }\end{array}$ & $\begin{array}{l}\text { Coaker (Price } \\
\text { N) }\end{array}$ & $\begin{array}{l}\text { Makere (Price } \\
\text { N) }\end{array}$ & \\
\hline Central & 800 & 1000 & 1400 & 1000 & 1000 \\
\hline Gonoigora & 900 & 1200 & 1600 & 1200 & 1200 \\
\hline Rigasa & 900 & 1100 & 1500 & 1100 & 1100 \\
\hline Barnawa & 950 & 1500 & 1600 & 1300 & 1300 \\
\hline Kakuri & 800 & 1000 & 1500 & 1000 & 1000 \\
\hline Sabontasha & 950 & 1200 & 1600 & 1200 & 1200 \\
\hline Kawo & 800 & 1050 & 1500 & 1050 & 1050 \\
\hline Ang. Rimi & 860 & 1050 & 1450 & 1050 & 1050 \\
\hline Kasuan-bachi & 800 & 1000 & 1500 & 1000 & 1000 \\
\hline Mando & 900 & 1100 & 1500 & 1100 & 1100 \\
\hline Average & 866 & 1120 & 1515 & 1100 & 1100 \\
\hline SD & 62.40 & 153.11 & 66.87 & 102.74 & 102.74 \\
\hline Min & 800 & 1000 & 1400 & 1000 & 1000 \\
\hline Max & 950 & 1500 & 1600 & 1300 & 1300 \\
\hline
\end{tabular}

Source: Field survey 2018

Marketing Margin Analysis and Marketing Efficiency;

Table 5. presents the estimates of net marketing margin and marketing efficiency in the selected markets. The net marketing margin ranged from $\$ 1100.00$ in Kakuri and Central market/Bakindogo (CM/B) to $\$ 1500.00$ in Barnawa market. Ayoola., et al (2008) opined that differences in net marketing margin could be attributed to differences in the socio-economic characteristics among the marketers. However, in this study, it could be linked to transfer marketing costs. Based on these reasons, the marketing of frozen fish in the study area is price

Table 5. Marketing Margin Per Carton of Shawa in Selected Markets.

\begin{tabular}{|c|c|c|c|c|c|}
\hline Selected Market & Supply Price & Selling Price & Market Margin & $\begin{array}{l}\text { Net Market } \\
\text { Margin }\end{array}$ & $\begin{array}{l}\text { Marketing } \\
\text { Efficiency }(\%)\end{array}$ \\
\hline Central Market & 7000 & 9000 & 2000 & 1100 & 22.22 \\
\hline Rigasa & 7500 & 9500 & 2000 & 1100 & 22.22 \\
\hline Goningora & 7500 & 9900 & 2400 & 1400 & 24.24 \\
\hline Kakuri & 7000 & 9000 & 2000 & 1100 & 22.22 \\
\hline Barnawa & 7500 & 10000 & 2500 & 1500 & 25 \\
\hline Sabontasha & 7500 & 9900 & 2400 & 1400 & 24.24 \\
\hline Anguarimi & 7250 & 9250 & 2000 & 1100 & 22.22 \\
\hline Kawo & 7000 & 9000 & 2000 & 1100 & 22.22 \\
\hline Mando & 7000 & 9000 & 2000 & 1100 & 22.22 \\
\hline Kasuanbagi & 7000 & 9000 & 2000 & 1100 & 22.22 \\
\hline
\end{tabular}

Source: Computed from Field survey 2018

Constraints of Marketing Frozen Fish in the Area.

Results of the major constraints affecting the marketing of frozen fish among marketer in the study area were presented in table 6 . The most highly rated constraint by the enterprise actors was transportation difficulties with a mean score of 6.11 . Transportation problems from within and outside the study area were reported. Kaduna is a land locked state and in recent times, due to distance of the study areas from the seaport, difficulty in hauling products from the ports to the wholesales destinations might have led to transportation challenges that could lead to occasional demand- supply gaps and associated price efficient. Meanwhile, the estimated ME showed that it was highest in Banarwa market and lowest in Central/Bakindogo. Many researchers held that wide variation in marketing margin and efficiency are indicators of inefficient marketing system and could lead to distortion in food market (Adegeye and Dittoh, 1985; Ayoola, et.al 2008). However, in this study little variation of 22.22 to 25.00 percent and $\$ 2000$ to $\$ 2500$ per carton of frozen fish was observed for marketing efficiency and marketing margin respectively. Thus, frozen fish marketing in Kaduna metropolis was found to be efficient. fluctuations. However, this finding is at variance with those by Omowa (2018) where middle men considered Price instability and price fluctuation of fresh catfish as major constraint facing the enterprise. Their study noted that the fluctuation was due to consumer's response to the law of demand and supply as no price regulation mechanism exists. Furthermore, marketing charges and storage losses were ranked second and third with a mean score of 4.56 and 2.94 respectively. Low profit and inadequate storage facility ranked fourth and fifth constraints in the study area. 
Table 6. Constraints faced by the marketers.

\begin{tabular}{|c|c|c|c|c|c|c|c|}
\hline Problems & 1 & 2 & 3 & 4 & 5 & Mean score & Ranks \\
\hline Poor Electricity Supply & 80 & 28 & 7 & - & - & 1.96 & $8^{\text {th }}$ \\
\hline High Electricity bills & 92 & 30 & 13 & - & - & 2.39 & $6^{\text {th }}$ \\
\hline inadequate Capital & 70 & 35 & 8 & 2 & - & 2.15 & $7^{\text {th }}$ \\
\hline inadequate storage Facility & 55 & 33 & 27 & - & - & 2.53 & $5^{\text {th }}$ \\
\hline Low Profit & 60 & 38 & 22 & 5 & - & 2.78 & $4^{\text {th }}$ \\
\hline Storage Losses & 48 & 32 & 21 & 10 & 4 & 2.94 & $3^{\text {rd }}$ \\
\hline Transportation Difficulties & 33 & 40 & 97 & 15 & 5 & 6.11 & $1^{\text {st }}$ \\
\hline Marketing charges & - & 35 & 40 & 25 & 15 & 4.56 & $2^{\text {nd }}$ \\
\hline
\end{tabular}

Source: Computed from Field survey 2018

\section{CONCLUSION AND RECOMMENDATION}

The study revealed that the enterprise actors (retailers and wholesalers) were young with wholesalers mean age (43 years) slightly above those of the retailers (41years). Differences exist in the price of frozen fish in the ten selected markets in Kaduna metropolis with highest consumer price of 1500.00 for Sadine at Barnawa market and lowest $\$ 800.00$ for Shawa in Central market, Kakuri and Kasuan-bachi. Frozen fish is price efficient and profitable in the study area with a rate of returns of about 0.11 and 0.22 for retailers and wholesalers respectively. It was recommended that road networks and formidable marketing system should be provided to further increase the profitability of the enterprise.

\section{REFERENCES}

Aasa, O S. (2006): 'Analysis of the Factors Affecting the Marketing and Demand for Certified Maize Seed in Kaduna State' Nigeria. An unpublished Msc Thesis, Department of Agricultural Economics and RuralSociology, Faculty of Agriculture, Ahmadu Bello University Zaria Nigeria pp29—50

Aasa, O. S, Ariyo, C. O, Ariyo, M. O, Olagunju, S and Olafemi, S, (2011); Marketing of Irish Potato in Kaduna Metropolis, Kaduna State, Nigeria. International Journal of Agricultural Development Economics (IJADE) 1(2] : 84-94

Aasa O. S., Alabi O.F, Ariyo C.O, Awotide O.G and Adetunji A. J (2015) : Factors Influencing the Marketing Demand of Certified Maize Seed (CMS) in Birnin Gwari Zone of Kaduna State, Nigeria. Nigeria Journal of Agricultural and Development Economics (NIJADE). 5. (1): 81-91

Adegeye, A.J and Dittoh, J.S (1985): Essentials of Agricultural Economics. Impact Publishers. Nigeria Ltd., pp 164-165 Ben Ahmed and Raphael Omolehin (1999). An analysis of Maize Marketing in Northern Nigeria: In Badu-Aprakuet al, Proceedings of the Regional Maize Workshop 4-7 $7^{\text {th }}$ May, 1999. IITA-COTONOU, Benin Republic Pp 419-432
Coster, A.S and Otufale, G.A (2012).Economic Analysis of Frozen Fish Marketing In IjebuOde Local Government Area, Ogun State, Nigeria; Res. J. Soc. Sci. 1(5): 96-101

Esiobu, N. S and Onubuogu, O.C (2014). Socieconomic Analysis of Frozen Fish Marketing in Owerri Municipal Council Area, Imo State, Nigeria: An Econometric Model Approach.Journal of Agricultural Science Vol 4(8), pp449-459

FAO (2014). The state of world fisheries and aquaculture. Opportunities and challenges. Rome, Italy: FAO

NBS, (2018): National Bureau of Statistic demographic Bulletins.

Olukosi, J. O. and Ehrbbor, P.O (2008) Introduction to Farm Management EconomicsAgitab Publication Zaria

Olukosi, J. O. and Isitor, S.U (1990): Introduction to Agricultural Marketing and Prices, Principles and Application. Living Book Series G.U Publication Abuja, Nigeria pp $\quad 1-4,68$

Omowa A.E (2018). Marketing of Processed Catfish in KadunaMetropolis Kaduna State, Nigeria.A dissertation submitted to the Department of Agricultural Economics and Rural Sociology, Ahmadu Bello University Zaria, Nigeria. (M.Sc) in Agricultural Economics.

Ndu, N. R. (2006): Fish Farm Layout, Pond Construction, Management and Maintenance Hatchery Techniques. A paper presented at the National Workshop on the Principles and Techniques of Fish Farming Organized by Nigerian Agricultural, Cooperative and Rural Development Bank, Kaduna, with collaboration of Life Riches consulting. Life RichesPublishers.95-97

Tomek, W.G and K.L Robinson, (1981): Agricultural Products Prices ( $2^{\text {nd }}$ edition) Cornell University Press NewYork U.S.A. International license viewed via https://creativecommons.org/licenses/by/4.0/ which permits unrestricted use, distribution, and reproduction in any medium, provided the original work is cited appropriately. 